Journal of Social Sciences 6 (4): 542-562, 2010

ISSN 1549-3652

(C) 2010 Science Publications

\title{
Sexting and Youth: Achieving a Rational Response
}

\author{
Nancy E. Willard \\ Center for Safe and Responsible Internet Use, United States of America
}

\begin{abstract}
The term "sexting" is a combination of two terms "text" and "sex". The term is being applied to situations to sending self-created nude or semi-nude sexually provocative images or sexually explicit text. Most of the focus has been on sending nude images-because these are far more likely to be more widely disseminated and because the distribution of these images can place young people at higher risk (the term is also, unfortunately being applied to situations where adults are sending nude images or explicit text from minors. This is an inappropriate use of the term. These activities should be called what they are: exploitation of a minor). This document will outline the research findings about this phenomenon, discuss the concerns about current degree of overreaction, address legal issues and provide recommendations for changes in criminal statutes and for the establishment of an effective multidisciplinary approach to investigate and intervene in these situations.
\end{abstract}

Key words: Sexting, child pornography, school officials, nude or semi-nude, sexual harassment, district attorney

\section{INTRODUCTION}

Among teens, the sexting phenomenon appears to be the result of a combination of factors: digital imaging technology that can easily capture and send images, impulsivity, raging hormones, peer or partner pressure and teen's biological incapability of effectively predicting the potential negative harmful consequences of their actions.

However, a November 2009 article on the AARP web site, entitled C*U*2nite: Sexting not Just for Kids, noted (Leshnoff, 2009):

More and more of the $50+$ set, both single and married, are using text messaging to spice up their sex lives. Boomers, often sandwiched between teenagers, aging parents and busy work schedules, are taking advantage of the new technology because it's fast, easy and fun

Given this apparent cross generational adoption of this behavior, there are clear indicators that this behavior should be considered within the range of normative human sexual behavior. This being said, there are significantly greater risks when teens engage in this behavior. The risks are associated with the mercurial nature of their personal relationships, the fact that teens can more easily be persuaded to provide such images, the degree to which these images can become widely disseminated and the resulting damage to the reputation of the person and the potential that these images can place young people at greater risk of exploitation.

Research insight: Three recent studies have outlined this new phenomenon.

Sex and tech: The National Campaign to Prevent Teen and Unplanned Pregnancy and CosmoGirl.com commissioned a 2008 survey of teens and young adults to explore electronic activity (http://www.thenationalcampaign.org/sextech/). The Sex and Tech survey of young people ages 13-26 found:

- A significant number of teens (ages 13-19) have electronically sent or posted online, nude or seminude pictures or video of themselves. $20 \%$ of teens overall, $22 \%$ of teen girls, $18 \%$ of teen boys and $11 \%$ of young teen girls (ages 13-16)

- $\quad$ Sending and posting nude or semi-nude photos or videos becomes even more frequent as teens become young adults (ages 20-26). 33\% of young adults overall, $36 \%$ of young adult women and $31 \%$ of young adult men

- $\quad$ Sexually suggestive messages (text, email, IM) are even more prevalent than sexually suggestive images and involvement also increases with age. $39 \%$ of all teens, $37 \%$ of teen girls, $40 \%$ of teen boys and $48 \%$ of teens say they have received such messages. $59 \%$ of all young adults, $56 \%$ of young 
adult women, $62 \%$ of young adult men and $64 \%$ of young adults say they have received such messages

- The images are frequently being sent in the contest of personal relationships. $71 \%$ of teen girls and $67 \%$ of teen guys who have sent or posted sexually suggestive content say they have sent/posted this content to a boyfriend/girlfriend. $21 \%$ of teen girls and $39 \%$ of teen boys say they have sent such content to someone they wanted to date or hook up with.15\% of teens who have sent or posted nude/semi-nude images of themselves say they have done so to someone they only knew online

- The images are frequently shared beyond the original recipient. $36 \%$ of teen girls and $39 \%$ of teen boys say it is common for nude or semi-nude photos to get shared with people other than the intended recipient

- Pressure from partners or peers is clearly a factorespecially for the teen population. $47 \%$ of teens (38\% of young adults) say "pressure from guys" is a reason girl and women send and post sexually suggestive messages and images. About $24 \%$ of teens (20\% young adults) say "pressure from friends" is a reason guys send and post sexually suggestive messages and images

Digital abuse survey: The MTV-associated press poll digital abuse survey, released in 2009 found (http://www.athinline.org/about Scan down the page to find the links to the reports):

- $24 \%$ of 14-17 year olds reported some involvement in sexting, either sending or receiving. $33 \%$ of 18 24 year olds had some engagement

- $10 \%$ of 14-24 year olds have sent a sexual image. Unfortunately, this data was not broken down into teen and young adult populations

- Most sent the image to a significant other or romantic interest. But $24 \%$ sent the image to someone they wanted to hook up with and $29 \%$ sent the image to someone they only knew online. Again, this data was not broken down into teen and young adult populations

- Of significant concern, $61 \%$ of those who sent an image said they had been pressured by someone else to do so. This data was not reported based on gender

Teens and sexting: In a national survey of teens ages 12-17 that uses cell phones, the Pew Internet and American Life Project Teens and Sexting study also $\begin{array}{llll}\text { released } & \text { in } & 2009 & \text { found }\end{array}$ (http://pewresearch.org/pubs/1440/teens-sexting-textmessages):

- $4 \%$ of teens said they had sent sexually suggestive nude or nearly nude images of themselves to someone else via text messaging (if you look closely at the age group differences and the increase in activity with age, it appears that the Pew and MTV findings are roughly equivalent for the teen population. Pew reported on youth ages 12 to 17 and MTV reported on youth ages 14-24. In Pew $8 \%$ of 17 year olds had sent an image. In MTV $10 \%$ of 14 to 24 year olds had sent an image. The earlier survey reports were higher. It is unknown why the difference-although one theory may be that the incident rate is rapidly diminishing. Self-report surveys always have a degree of unreliability especially when assessing behavior that is not considered to be "appropriate")

- $15 \%$ of teens said they had received sexually suggestive nude or nearly nude images

- Older teens were much more likely to send and receive these images. $8 \%$ of 17 -year-olds had sent images and $30 \%$ had received them

The focus groups revealed that there are three main scenarios for sexting:

- Exchange of images solely between two romantic partners

- Exchanges between partners that are shared with others outside the relationship

- Exchanges between people who are not yet in a relationship, but where at least one person hopes to be

Common findings: Thus, across these three studies, very common patterns are emerging:

- A minority of teens are engaging in sexting activity. Involvement clearly increases with age

- A significant amount of this activity is related to personal relationships. This includes current relationships and desired relationships

- Boys and girls are participating in this activity at an equivalent rate

- A significant portion of teens report that pressure by others to provide these images is an issue

Kinds of situations: As noted in these studies, the most common sexting scenarios involve exchanges between romantic partners or where there is an interest in a 
partnership. These exchanges, which are intended to be private, can result in a wider dissemination of the image. This is sometimes by mistake, but also sometimes in a malicious manner, as will be discussed below. The term "desired relationships" could include situations that range from one teen desiring a close personal relationship with a specific other person to situations where a teen is engaging in a wide-ranging search for sexual "hook-ups".

With combined insight from research, news articles and reported incidents, the following kinds of situations have been noted as occurring.

\section{Developmentally normative:}

Not intended to cause harm, but mistakes could lead to distribution: (Note, all of these activities are similar to what young people have engaged in, throughout time, in the course of normal sexual development-but before digital media technologies were available for recording and transmitting evidence of this behavior):

- Exchange within a romantic partnership or a desired romantic partnership where neither partner pressured for the image or distributed the image beyond each other

- Exchange within a romantic partnership where neither partner pressured for the image, followed by a small private distribution of image by one partner to some friends to "show off". This is done with no intent for the image to be distributed further or to cause harm, but sometimes the image is disseminated by a third party recipient

- The digital media enhanced version of "show me yours and I'll show you mine", "spin the bottle", or a "truth or dare" game. There is no initial intent to distribute further or to cause harm, but sometimes things get out of hand and the images are disseminated

- Creation and dissemination of image or materials for entertainment, attention-getting purposes, or to "gross others out"-e.g., a "bawdy" video created at a party

Harassment:

Intended to cause harm to person depicted or that constitutes harassment:

- Malicious, widespread distribution

- Peer pressure or peer trickery-with intent to distribute

- An image taken under circumstances where privacy is expected, like in a locker room
- An image that was being retained privately, such as an image created and never disseminated or image that was shared only with a partner, that is released by someone else who gained access to device on which the images were stored

- Fake image created by merging a photo of a teen on a nude body image found elsewhere

- Image sent as a form of harassment-to a recipient who does not want to receive the image

\section{At-risk:}

Teen depicted is engaging in at-risk behavior:

- Intentional dissemination of an image by the teen depicted as attention-getting behavior or to advertise sexual availability with like-age peers

- The teen depicted is engaging in solicitation of sexual "hook-ups" with older teens or adults or is engaged in teen prostitution

\section{Exploitation:}

The situation involves sexual abuse or other significant harm:

- Demand for an image by partner in an abusive, controlling relationship

- Revengeful distribution by a partner after a break-up

- Blackmail threat by recipient of image to disclose the image to others unless the person depicted engages in some other action. Frequently, this is an abusive partner and with a demand to engage in sexual activity

- Sexual solicitation of a younger teen by an older teen

- Abusive or coercive acquisition of image, with intent to widely distribute

Revenge porn/cyberbully sexting: Specific note must be made about malicious use of these images. Revenge porn has an entry in the Urban Dictionary: (http://www.urbandictionary.com/define.php?term=rev enge\%20porn) "Homemade porn uploaded by ex girlfriend or (usually) ex boyfriend after particularly vicious breakup as a means of humiliating the ex or just for own amusement". There are web sites set up to allow for such postings. Conduct a search on the term "revenge porn". Here are some web site descriptions:

- ExGirlfriend Revenge: She loved getting naked for her bf before cheating on him so he decided to send this to us to post!

- The hottest topic on relationships becomes one of the most popular porn video downloads. Watch 
jilted lovers get their revenge as they submit hardcore porn

Revenge porn is affecting both adults and teens. Several teen incidents are described as follows: Alex Phillips, 17, of La Crosse, Wisconsin posted two nude images of his ex-girlfriend on his MySpace page (http://www.citmedialaw.org/threats/wisconsin-vphillips). His girlfriend had emailed the pictures to him when they were dating, but the relationship had broken up and she started seeing another guy. In the captions, Phillips exceptionally nasty comments. The State charged him with him with criminal libel, possession of child pornography, sexual exploitation of a child and causing mental harm to a child. In January 2009, Phillips pled guilty to causing mental harm to a child.

In Thurston County, Washington, three teens were arrested in January 2010 (Pawloski, 2010). A middle school girl had sent a nude image to her boyfriend. They broke up. He sent the image to one girl, who sent it to another, who sent it to many.

Cyberbully sexting is a term developed for use in this study. Among teens peer-led bullying has taken on a new dimension. The objective of a group or individual bully is to trick an intended target into providing an image that is then send this to others or used for blackmail. Several variations include invasion of privacy by obtaining an image without permission such as in a locker room or finding an image on the target's device and forwarding it and creating a fake image merging a photo of a person's head onto a nude image and creating a fake profile of a "hot teen" to trick someone into providing an image. These are some privately reported incidents:

Freshman girl was bugged and bugged by an upper classman boy to send him a nude image. Finally she did. He then sent it to others at the school

A girl student left her cell phone on the desk in the library where she was working with a group of students. One student grabbed the phone, looked through the stored images, found a nude image and sent it to his own phone, from which he then forwarded to many other students

A student created a fake profile of a "hot boy" and was encouraging girl students to send him nude images

What is becoming evident as these sexting situations come to light is that the ones that appear to lead to the widest dissemination and greatest emotional harm are those that involve the malicious dissemination either after a relationship break-up or in the context of cyberbullying.

As noted in an article discussing this phenomena (Mordan, 2008): "Revenge porn is difficult to prosecute because there are no statutes specifically outlawing the practice". Obviously, this is something that must be corrected-for teens as well as adults.

\section{Underlying factors:}

Sexualization of youth: In February, 2007, the American Psychological Association Task Force on the Sexualization of Girls issued a report that concluded that the proliferation of sexualized images of girls and young women in advertising, merchandising and media is harmful to girls' self-image and healthy development. This report noted investigated the concerns about sexual media found in virtually every form of media, including television, music videos, music lyrics, magazines, movies, video games and the Internet, as well as advertising campaigns and merchandising of products aimed toward girls.

As noted in the press release for the report:

Research evidence shows that the sexualization of girls negatively affects girls and young women across a variety of health domains:

- Cognitive and emotional consequences: Sexualization and objectification undermine a person's confidence in and comfort with her own body, leading to emotional and self-image problems, such as shame and anxiety

- Mental and physical health: Research links sexualization with three of the most common mental health problems diagnosed in girls and women--eating disorders, low self-esteem and depression or depressed mood

- Sexual development: Research suggests that the sexualization of girls has negative consequences on girls' ability to develop a healthy sexual self-image

While the focus of this report was on the harm to girls, surely, the proliferation of sexualized images is also affecting boy's self-image and attitudes, as well as their perceptions about girls and appropriate sexual behavior.

It is necessary to more effectively to challenge this pervasive provocatively sexual messaging directed at young people. We must also ensure that young people gain skills in understanding and rejecting these influences and that they gain the insight and personal relationship skills to effectively negotiate the terrain as they are maturing sexually. 
Differences between boys and girls: As noted, both boys and girls appear to be engaging in this activity in equivalent numbers. However, it appears that girls are more likely than boys to be pressured to provide such images. There also appear to be significant differences in how these situations play out and are perceived by adults (for an additional example, the APA report focused on sexualization of girls and failed to address the concerns of the sexualization of boys).

In news stories that address incidents where the image of a teen girl has been disseminated concerns are expressed about the damage to the girl's reputation, that this image will end up being trafficked in child pornography collections, or that the girl is at risk of being contacted by an online predator. Also, girls or women are far more likely to be the subject of retaliatory harm on the revenge porn sites.

In stories reporting on incidents related to images sent by boys there is rarely a concern expressed about potential harm to the boy's reputation or concern about the potential of exploitation. The reaction appears to range from considering the transmission of such images to be normative behavior to considering boys to be sex offenders.

Several examples of this phenomena are illustrated: On January 15, 2010, the US Court of Appeals for the 3rd Circuit heard arguments in the case of Miller v. Skumanick (Duffy, 2010). This case originated 2008 when a school district learned that some nude and seminude images of girls were circulating, confiscated students' cell phones and turned the photos in question over to the district attorney, Skumanick. Skumanick sent a letter to the girls and their parents, offering an ultimatum. They could attend a five-week re-education program of his own design, which included topics like "what it means to be a girl in today's society" and would also be placed on probation, subjected to random drug testing and required to write essays explaining how their actions were wrong. If the girls refused the program, they would be charged with felony child pornography.

The images of the girls whose parent's challenged this threat involved one image of two girls in their training bras, taken at a slumber party and another of a girl coming out of the shower who was partially wrapped in a towel. Another image was of a girl in a bathing suit that Skumanick indicated was child pornography because she was posing "provocatively".

The parents of three of the girls refused this forced education and contacted the American Civil Liberties Union (The TRO and all of the briefs are on the ACLU site at: http://www.aclupa.org/legal/ legaldocket/milleretalvskumanick). In March 2009, a federal judge granted a temporary restraining order preventing the district attorney's office from going ahead with any prosecution (http://www.pamd.uscourts.gov/opinions/munley/09v54 0.pdf). On January 15, the US Court of Appeals for the 3rd Circuit heard arguments on an appeal from this TRO.

An interesting note was pointed out in an ACLU blog (Keelty, 2010). The girls who appeared in the photos were threatened with charges of child pornography. If the district attorney considered these images to be pornographic, why were there no charges filed against the boys who were transmitting them? Reportedly, when before the Third Circuit, the attorney for the district attorney explained how, after the girls were photographed, "high school boys did as high school boys will do and traded the photos among themselves".

Also in this case, the district attorney argued that it was necessary threaten the girls with felony prosecution because by creating these images they had placed themselves at risk of sexual predation (Brief for Skumanick. On the ACLU site).

By contrast, is the story of Phillip Alpert (Feyerick and Steffen, 2009). Philip had just turned 18. He had gotten into an argument with his 16 year old girl friend and in a moment of anger send a naked photography of her to many friends and family. Alpert was arrested and charged with sending child pornography, a felony. He pleaded no contest and was convicted. He was sentenced to five years probation and is required by Florida law to register as a sex offender.

Another story is that of Evans Cesar (Alspach, 2010). This 18 year old Brockton High student was arrested because he was found to have a graphic sexual video on his cell phone. The video was of a male and female who appear to be teenagers or young adults and depicted oral sex. The students said the video was widely circulating in school. Cesar said he received the video, but did not send it.

On initial analysis, most adults would likely think that girls are more risk from sexting. Both are at risk. Teen girls appear to be more likely to be pressured to provide images, to have the images spread with resulting damage to their reputation, to be the recipient of retaliatory distribution and to place themselves in a position for further potential exploitation.

The mixed messages given to teen boys around this issue place them at exceptionally high risk. Many adults are likely to consider teen boy interest in these images and distribution behavior to be normal behavior. Because of this perception, teen boys are not likely to 
consider the potential criminal ramifications. Especially when boys turn 18, they are at a significantly higher risk of a life and future destroying action if they send a nude image to a minor, ask for a nude image from a minor, or distribute a nude image of a minor. They are the ones who will be arrested, prosecuted and required to register as a sex offender. One day, "boys will be boys"-the next, they are registered sexual offenders and their life is destroyed.

Overreaction and techno-panic: Although published before the very recent overreaction about sexting, a review written by Chaffin (2008), Professor of Pediatrics, University of Oklahoma Health Sciences Center of the book, An American Travesty: Legal Responses to Adolescent Sex Offending (Zimring), frames the challenge of overreaction that we are currently witnessing (http://www.bsos.umd.edu/gvpt/lpbr/subpages/reviews/ zimring 1004.htm):

This is not a good time in history to be a teenager caught engaging in illegal sexual behavior. Although proponents might argue, with some reason, that our current and very aggressive legal and treatment response to these youth represents an improvement over years of blindness and silence, it is almost a given that advocacy tends to be followed by excess. "Boys will be boys" has given way to moral panic about sex offenders and perceptions of these youth as uniquely dangerous, recidivistic and possessed by the demon of hidden sexual abnormalities which can be driven out only by aversively overpowering the resistance of the possessed and his family. Youth may undergo years of compelled therapy, in which they must conform their thinking to a therapy-model which assumes that their behavior is part of a compulsive and repetitive "cycle". They may be required to keep journals of deviant sexual fantasies and, most of all, required to confess. Confess their deviancy and differentness. Confess their past offenses-incriminating themselves if need be. Confess that their ostensibly normal social behavior is "victim grooming". Confess that their motives are rarely benign. Confess that they are and always will be a sex offender. Failure to espouse the correct beliefs about oneself as different, deviant and at continual risk may be grounds for loss of basic freedoms and sanctions
... No other type of juvenile offender is viewed with such suspicion and no other type of juvenile offender experiences comparable exceptions to customary juvenile justice and treatment philosophies

Concerns expressed by adults related to youth use of the Internet and other digital media can be aptly characterized as Techno-Panic-heightened level of concern about the use of contemporary technologies by young people that is disproportionate to the empirical data on the actual degree of risk (Roush, 2006; Cohen, 1972). Since 1995, the Techno-panic eras related to the Internet and cell phones have been: pornography, predators, cyberbullying and now sexting. In fact, it appears that the Techno-Panic related to sexting is a culmination of all of the other panics.

By way of example, in 2000, the Crimes Against Children Research Center (CACRC) issued a report on a Youth Internet Safety Survey (Finklehor et al., 2001). This report stated that: "Almost one in five (19\%) of the young Internet users surveyed received an unwanted sexual solicitation in the past year". While these findings were widely reported as situations where dangerous adult predators were soliciting youth, In fact, the term "sexual solicitations" included unwanted communications of a sexual nature. Forty-nine percent of those communications came from other teens and only $4 \%$ were identified as coming from older adults. The vast majority of youth were not distressed and all effectively handled the situation. A later study found that 1 in 7 youth had "been sexually solicited" with similar underlying findings.

Despite the fact that the overwhelming majority of these situations could more appropriately be characterized as sexual harassment by teens, young adults, or possibly teens pretending to be young adults, inaccurate information about this study is prevalent. On the Florida Attorney General Child Predator CyberCrime Unit web site is the following statement (http://myfloridalegal.com/pages.nsf/Main/DF75DF6F5 4BDA68E8525727B00645478): "Nationally, one in seven children between the ages of ten and 17 have been solicited online by a sexual predator". Alternatively, the US Department of Justice refers to the teens who sent unwanted sexual messages as "predators" and offenders" (http://ojp.usdoj.gov/ovc/publications/bulletins/internet _2_2001/internet_2_01_6.html).

Recent research from CACRC, which provides technical support to the Internet Crimes Against Children Task Forces, found that in 2006, there were just over 600 arrests of online sexual predators in cases 
involving actual victims (Wolak et al., 2009). This is just $1 \%$ of all arrests for the sexual abuse of minors. The Texas Attorney General states on his web site: "The proliferation of child predators using the Internet to target young victims has become a national crisis. A study shows one in seven children will be solicited for sex online in the next year" (https://www.oag.state.tx.us/criminal/

cybersafety.shtml). On the Pennsylvania Attorney General web site it states: "The growth of the Internet has been astronomical and regrettably, predators are using the Internet as their primary means of contacting and communicating with their young victims" (http://www.attorneygeneral.gov/crime.aspx?id=56).

A recent commentary on concerns of the treatment of juvenile sex offenders written by Chaffin (2008), published in Child Maltreatment is entitled: Our Minds Are Made Up-Don't Confuse Us With the Facts: Commentary on Policies Concerning Children With Sexual Behavior Problems and Juvenile Sex Offenders. For the last decade, law enforcement has frequently presented information regarding online sexual predators that was not grounded in fact.

It is imperative that we address the sexting issue based on an approach that is grounded in "fact"-with an understanding of normal teen sexual development-not a techno-panic-driven overreaction grounded in the fact that teens are now able to engage in sexual-related behavior using these new technologies.

\section{Criminal legal issues:}

Child pornography: Efforts are underway in several states, including Arizona, Pennsylvania and Indiana, to criminalize sexting (Rau, 2010; Swift, 2010; Seidel, 2010). Representations have been made that at this time the only criminal statutes available to address this concern are those against child pornography or sexual exploitation of a minor. Amendments to these statutes are proposed to provide a lesser offense has been promoted as a protection for minors. These "protections" would criminalize the creation of these images, as a lesser charge, but still a crime.

Additionally, in many states, law officers are regularly telling young people that if they sext they can be arrested for child pornography. Here is a sample message (this is taken from an actual brochure produced by law enforcement. I decided not to identify the source because I am going to criticize this):

In addition to damaging your reputation, you could be charged with a crime for making such a photograph. If you are under 18, any photograph you take of yourself in a nude or provocative pose is technically considered child pornography. And if you send that photo to someone, you are disseminating child pornography. Teens in some states have been charged with felony crimes! If you are found guilty, a felony record could follow you for life and you may have to register as a sex offender. This registration requirement will follow you to college or university campus and your future places of employment

Recall the MTV data. Twenty-four percent of 1417 year olds reported some involvement in sexting, either sending or receiving nude images. Is our country prepared to prosecute one-fourth of the American teen population for creating, possessing, or distributing nude images? Laws against the production, dissemination and possession of sexually explicit images of minors have been enacted to prevent the abuse of minors-not to convict minors.

A case involved a "show me yours and I'll show you mine" exchange of images resulted in the arrest of a 12 year old boy and 13 year old girl in Indiana (McElroy, 2010). The boy "had sent a text and picture of his exposed genitals ... and requested that she do the same". Police said the girl had responded "via phone and text a picture of her nude exposed body and breasts". Both are now facing felony charges for child exploitation and child pornography charges.

The purpose for laws against child pornography was outlined in the US Supreme Court case Ashcroft v. Free Speech Coalition (535 US 234 (2002)). This case is instructive because it addressed the question of what does not constitute child pornography. The Court struck down two overbroad provisions of Child Pornography Prevention Act of 1996 which sought to address the concern of "virtual child pornography" (created with digital technologies, not a real child). The Court outlined the concern to be addressed:

The sexual abuse of a child is a most serious crime and an act repugnant to the moral instincts of a decent people. In its legislative findings, Congress recognized that there are subcultures of persons who harbor illicit desires for children and commit criminal acts to gratify the impulses. ... Congress also found that surrounding the serious offenders are those who flirt with these impulses and trade pictures and written accounts of sexual activity with young children

The Court then set forth the basis upon laws criminalizing the creation, distribution and possession of child pornography address this concern: 
Ferber [458 US 747 (1982)] upheld a prohibition on the distribution and sale of child pornography, as well as its production, because these acts were "intrinsically related" to the sexual abuse of children in two ways. Id., at 759. First, as a permanent record of a child's abuse, the continued circulation itself would harm the child who had participated. Like a defamatory statement, each new publication of the speech would cause new injury to the child's reputation and emotional well-being. See id., at 759 and n. 10. Second, because the traffic in child pornography was an economic motive for its production, the State had an interest in closing the distribution network. "The most expeditious if not the only practical method of law enforcement may be to dry up the market for this material by imposing severe criminal penalties on persons selling, advertising, or otherwise promoting the product". Id., at 760. Under either rationale, the speech had what the Court in effect held was a proximate link to the crime from which it came

Later, in Osborne v. Ohio, 495 US 103, (1990), the Court ruled that these same interests justified a ban on the possession of pornography produced by using children. "Given the importance of the State's interest in protecting the victims of child pornography", the State was justified in "attempting to stamp out this vice at all levels in the distribution chain". Id., at 110. Osborne also noted the State's interest in preventing child pornography from being used as an aid in the solicitation of minors. Id., at 111. The Court, however, anchored its holding in the concern for the participants, those whom it called the "victims of child pornography". Id., at 110. It did not suggest that, absent this concern, other governmental interests would suffice. See infra, at $13-15$

Clearly, the underlying rationale for laws against child pornography is to prevent the sexual abuse of a minor and intended for distribution to those "subcultures of persons who harbor illicit desires for children and commit criminal acts to gratify the impulses". This is a different situation than what is involved in the majority of teen sexting situations, such as the one outlined above. These images were not created under conditions of abuse and were not intended for distribution to those who want to sexually exploit minors. Contrast the above incident with the following incident:

A 14 year old student was blackmailing high school students to provide him with nude images. When arrested, he had hundreds of images on his IPod and Cell phone. "Our suspect is just very good at complimenting these young girls and telling them how pretty they look. It starts out with him just asking for clothed pictures and then, 'Can you send me one a little more risqué, maybe in your bra and panties and then from there he tries to get nude pictures,"' Greenfield police Detective Sgt. Dave Patrick said

Note the possession of hundreds of images, which provides indications that the boy was engaged in collection behavior, as well as the sophisticated techniques used to groom the girls to provide these images. Given the size of his collection and the sophistication of his grooming techniques, there is reason to suspect that he was engaged with and being coached by more accomplished pornographers. Further, in this situation, the boy who obtained the images through coercion was arrested, not the girls who created the images. This situation is closer to the intent of laws against child pornography.

However, as the objective of juvenile jurisdiction is rehabilitation, charging an offense that would not result in registration as a sex offender is preferable. As noted by Chaffin (2008) in his commentary:

Fortunately, the facts as we know them about children with sexual behavior problems and teen sex offenders paint a far more optimistic picture than popular misperceptions would suggest. Given some sort of credible intervention, long-term risk is generally low and not unusually different from that of many other common and far larger juvenile groups. Recidivism hazard rates decline quickly, suggesting that we do not need to take a longterm risk focus with the vast majority of these youth

...

Moral panic, righteous indignation and truthiness have their own allure and satisfaction. The sound bite that we should put our kids' safety before the rights of sexual offenders, adult or juvenile, sounds so intuitively correct that it is a guaranteed political winner, even if the policy it promotes 


\section{J. Social Sci., 6 (4): 542-562, 2010}

is ultimately destructive and fails to deliver the child protection goods

Under federal law, child pornography is any visual depiction, where (A) the producing of such visual depiction involves the use of a minor engaging in sexually explicit conduct and (B) such visual depiction is of such conduct (18 USC $\S 2252$ ). "Sexually explicit conduct" includes any form of actual sex or the "lascivious exhibition of the genitals or pubic area" (18 USC $\S 2256$ ).

Most Courts weigh what are called the Dost factors to determine whether the images meet this standards (United States v. Dost, 636 F. Supp. 828 (S.D. Cal. 1986)): (1) was the focal point of the visual depiction the child's genital area; (2) was the setting sexually suggestive; (3) was the child depicted in an unnatural pose or inappropriate attire given his age; (4) the degree of nudity; (5) did the image suggest sexual coyness or a willingness to engage in sexual activity; (6) was the image intended to elicit a sexual response from the viewer.

Clearly under the Dost factors, the focus of the inquiry is on whether the images are designed to encourage the sexual abuse of minors (Police: boy threatened 7 girls into sending nude photos. WISN http://www.wisn.com/news/21298574/detail.html).

Some sexting images are likely to meet the Dost standards. Others will not. Even if the images do meet the Dost standards, if the image has not been produced under conditions of abuse or coercion of the minor depicted, it is not child pornography. A teen who has self-produced and distributed sexually explicit images could most likely be brought under juvenile jurisdiction as prostitution, solicitation, or indecent exposure or as a status offense. However, an adult who engages in possession or dissemination of an image self-created by a minor should still be subject to laws against child pornography.

Harmful unintended consequence: Of even greater concern are the unintended consequences of telling teens that if they self-produce child pornography they could be arrested, even under a misdemeanor charge is the incredibly harmful impact this will have on the willingness of young people who really are being abused to report such abuse.

The Amicus Brief filed in the case of Miller v. Skumaneck by the Justice Law Center outlines the most compelling reason for not applying laws against child pornography against minors-it will increase the harm of actual sexual abuse (http://www.aclupa.org/downloads/Amicusmiller.pdf).
The statute seeks to protect minors manipulated and abused in the creation of child pornography, supra Part IC1 this purpose is not served by prosecution of an adolescent's consensual act of self expression via sexting. Rather, the threat of prosecution for appearing as a subject in alleged child pornography would serve to deter children who are real victims of exploitative sexual abuse in the production of video or photographic child pornography. ...

Exposing vulnerable, molested children to prosecution as accomplice to the atrocious crimes of their abusers serves no positive purpose and is instead likely to frighten children away from reporting their abuse for fear of being criminally charged themselves. Children who have suffered the terrible ordeal of sexual abuse in the creation of child pornography are often silent about the experience and may blame themselves for the crimes of their abusers. Goodman-Brown, Why Children Tell: A Model of Children's Disclosure of Sexual Abuse, 27(5) Child Abuse and Neglect 525, 528 (2003) (finding "[f]or many reasons, children who have been sexually abused may come to believe that they are at least partially responsible for their own abuse" and delay disclosure). Developmental factors, including the natural egocentrism of children, may cause children to assume responsibility for events in which they are involved, regardless of their role under the circumstances. Id

The United States Supreme Court recently acknowledged that underreporting is already "a common problem with respect to child sexual abuse" and cited research reporting that about $88 \%$ of female rape victims under the age of 18 did not disclose their abuse to authorities. Kennedy v. Louisiana, 128 S.Ct. 2641, 2663 (2008) ... (citing Hanson, Factors Related to the Reporting of Childhood Rape, 23(6) Child Abuse and Neglect 559, 564-65 (1999) (finding that $88 \%$ of female rape victims under the age of 18 do not report their abuse)). Research shows that children often weigh the consequences of their actions prior to disclosing abuse and are less likely to disclose sexual abuse if they blame themselves for the abuse. Goodman-Brown, supra, at 528, 537-38. A state policy of prosecuting the child 


\section{J. Social Sci., 6 (4): 542-562, 2010}

exploited in the production of child pornography as an accomplice would further encourage children to blame themselves and deter disclosure

Teens make mistakes. They do not always follow the rules-if they did, there would be no teen drinking, smoking, or drug use. Worse, sometimes they will be pressured, abused, or extorted by others to provide these images based on the misrepresentation that this abuser loves them and the promise the image will be kept private. Especially online, predators are known to use grooming techniques that involve a process of seeking ever more revealing images-such as the strategy described earlier used by the 14 year old who was soliciting images.

The extraordinarily harmful unintended consequences of these legislative and education efforts that seek to penalize the teen depicted in the image and criminalize that teen's behavior will include:

- Youth who are sexually abused and photographed will be more afraid to report because they know they would be charged as accomplices, thus the abuse will continue

- Youth, who in an impulsive moment provided an image, can be easily blackmailed by threat of disclosure. The blackmail could include performing sex or engaging in prostitution. "If you don't have sex with me, or him, I will disseminate your image and you will be arrested"

- Youth who are faced with the no-win situation of massive public humiliation, arrest and prosecution may consider suicide to be a viable option

It is essential that state legislatures and law enforcement recognize that if they seek to address this new concern by criminalizing self-creation, they are placing minors at significantly higher risk of sexual abuse because it will create situations where teens who are actually being abused, tricked, or coerced into providing images will be afraid to report because they fear arrest.

Consensual sexting behavior that falls within the range of normative development behavior, where the participants are within a close age range, thus removing concerns of lack of actual consent and where no one shares the images beyond the original participants, should be addressed educationally and through counseling, not criminalization.

It is necessary to address the true harm caused by sexting through the criminalize of the behavior that actually causes the harm. This includes actions that violate the trust of the teen depicted by distributing the images further than the extent to which the teen depicted envisioned and, most especially, to criminalize malicious or egregiously harmful actions that have either pressured or coerced the teen into create the image or which have led to the wide distribution of the image, as well as those incidents where sexting is occurring in the context of other forms of sexual abuse.

For the teen whose self-creation has crossed the line from normative developmental behavior to selfexploitation, it there are already criminal statutory provisions, such as teen prostitution, solicitation, or indecent exposure, that should allow juvenile jurisdiction to ensure that the teen is placed in a remediation treatment program that will address this self-injurious and dangerous behavior.

Young adults: An additional challenging situation is that during their senior year of high school, most students turn 18 and are supposedly now able to think like adults. If an 18 year old sends a nude image to a minor, asks for or simply receives a nude image of a minor, or distributes a nude image of a minor, that student could more easily face felony arrest and registration as a sex offender.

Based on the findings of the Pew Internet study, $8 \%$ of 17 year olds had sent a nude image and $30 \%$ had received one. We can assume the percentage of 18 year olds who are engaged in this activity is relatively equivalent. Especially because these 18 year olds are immersed in a social environment with peers who are minors, we must expect that image sharing and requests will cross this legally-constructed line.

In a privately reported incident, a group of high school boys jointly created a "rowdy" video that included nudity. All but one of the students were 17. The unfortunate one had turned 18 several weeks before. The 17 year old students faced no legal consequences. The 18 year old student was arrested and is now a registered sex offender.

An effective legislative solution would create a safe-harbor exception for all sex crime laws that relate to sexting behavior, similar to that provided in statutory rape laws (Davis and Twombly, 2000). This would include laws related to provision of indecent materials to minors and the sexual exploitation of minors. This would allow teens and young adults who are roughly the same age to legally sext, but provide the ability to charge individuals in situations where a significant age gap between the participants calls raises questions about consent. The most common safe harbor age differential in various states appears to be 3-4 years difference in age. So as not to confuse youth, the age 
difference in these statutes should be similar to the age difference related to statutory rape. It will also be necessary to take into account situations where cognitive disabilities may also interfere with the ability to consent.

Distribution of images: The greatest harm to young people engaged in sexting is when the image is disseminated. There may be no criminal statutes that specifically address this situation. There is a civil law remedy (Restatement of the Law, Second, Torts, $\S$ 652D):

652D Publicity Given to Private Life. One who gives publicity to a matter concerning the private life of another is subject to liability to the other for invasion of his privacy, if the matter publicized is of a kind that (a) would be highly offensive to a reasonable person and (b) is not of legitimate concern to the public

Most, if not all, states have some form of an Invasion of Privacy statute. This statue generally applies in cases where someone creates a reproducible image of person who is fully or partially nude by obtaining such image in a place where privacy is expected. The statutes also generally prohibit the distribution of images obtained in such a manner to a third party.

This statute could be amended, if necessary, to include several different provisions related to nude or partially nude images that have been provided by the person depicted or from a third party. These provisions could:

- Prohibit the distribution of a nude or semi-nude image of a minor. (this would include images that would not meet the child pornography requirement of "sexually explicit". It is presumed that minors cannot legally consent to such distribution, even in circumstances where the minor has more widely distributed the image)

- Prohibit the distribution of a nude or semi-nude image of an adult without permission of the person depicted. (this will address the revenge porn problem)

- Coerce a person a person into providing a nude or semi-nude image. (Coercion is the act of forcing another party to provide such image by use of threats, intimidation, trickery, or some other form of pressure or force)

False light image: The PROTECT Act of 2003 was enacted subsequent to the decision in Ashcroft v. Free
Speech Coalition (Pub. L. 108-21, 117 Stat. 650, S. 151, enacted April 30, 2003). This Act used language that was carefully drafted to meet the standard enunciated in that decision, including the dissenting and concurring in part opinions.

This Act prohibits making "virtual child pornography"-a visual depiction that is a digital image, computer image, or computer-generated image of, or that is indistinguishable from an image of, a minor engaging in specified sexually explicit conduct.

The rationale of the prohibition on virtual child pornography remains the same as argued in Ashcroft, that virtual child pornography whets the appetites of pedophiles and encourages them to engage in illegal conduct, pedophiles may use virtual child pornography to seduce children and the possibility of producing images by using computer imaging makes it difficult to prosecute those who produce pornography by using real children.

The laws against virtual pornography do not address a concern that sometimes emerges in the context of sexting, which is when someone creates a virtual image that merges an image of a known minor onto a semi-nude, nude, or sexually explicit image, thus creating an image that places the known minor in a position of false light-appearing to be posing in this manner. Presumably, a sexually explicit image would meet the standards of virtual child pornography, but images that are nude or semi-nude might not.

Further, the rationale for the production of this false light image is different from the rationale for child pornography. The harm is grounded in the misrepresentation of the person depicted as engaging in behavior that is not what he or she has or would do that damages that person's reputation. This is the same harm that is addressed in the civil law tort of false light (Restatement of the Law, Second, Torts, § 652E).

652E. Publicity Placing Person in False Light. One who gives publicity to a matter concerning another that places the other before the public in a false light is subject to liability to the other for invasion of his privacy, if (a) the false light in which the other was placed would be highly offensive to a reasonable person and (b) the actor had knowledge of or acted in reckless disregard as to the falsity of the publicized matter and the false light in which the other would be placed

An additional provision could be added to the Invasion of Privacy statute that would prohibit producing, distributing, receiving, or possessing with 


\section{J. Social Sci., 6 (4): 542-562, 2010}

intent to distribute a nude or semi-nude image that places a person in false light.

Registration as sex offender: Concerns about the effectiveness of sex offender lists are rising (Knutson and Scheck, 2009; Pfeifer, 2009). Contrary to stranger danger warnings, the vast majority of offenders who abuse children and teens are known by or related to the victim. There is no evidence to demonstrate that sex registrations have made society safer. The registry lists are growing exponentially, resulting in a caseload that is impossible to manage. When there is no assessment of actual risk, the registry can act to dilute the amount of attention that is paid to the truly dangerous individuals.

Reflect back to the story of Philip Alpert. Yes, he should not have sent nude images of his girlfriend to many people. Yes, this was an act that required a legal consequence. But Philip sent those imaged during a brief period of intense anger. There are no indications whatsoever that Philip presents any risk of harm to anyone. Yet he is on a list with rapists and pedophiles. As reported (Feyerick and Steffen, 2009): “He's been kicked out of college, he cannot travel out of the county without making prior arrangements with his probation officer, he has lost many friends and is having trouble finding a job because of his status as a convicted felon". Of what possible value to society is it to destroy this young man's life and fill up the sex offender registry with someone who presents no risk of harm to other youth?

Given the degree to which sexting behavior has penetrated teen and young adult environment, the likely inability of teens to distinguish when actions that are common among their peers have crossed the line of acceptability and the ease with which actions with digital media can be taken impulsively, no teen or young adult should be required to register as a sex offender unless the actions of that teen or young adult are truly egregious and clearly demonstrate risk of that they may engage in sexual abuse in the future.

\section{School legal issues:}

On-campus actions: School officials have the authority and responsibility to respond to any harmful or inappropriate speech through the District Internet system and by students using digital devices at school to either take pictures or send them if those actions are inconsistent with the school's educational mission, Bethel v. Fraser (478 US 675 (1986)), or if the actions have created, or a reasonable person would perceive could create, a substantial disruption at school or interference with the rights of students to be secure, Tinker v. Des Moines (393 US 503, 507 (1969)).
This legal standard clearly gives school officials the authority to respond to on-campus acts of students related to sexting.

Off-campus actions: The majority of these pictures, are not, for obvious reasons, produced on campus. Many times they are also not being distributed on campus. Thus it is important for school officials to understand when and against whom, they can impose formal discipline. Some districts have implemented policies allowing for student discipline for sexting or have suspended students for such activities.

School officials have the authority to formally respond to off-campus speech if that speech has created, or a reasonable person would perceive it could create, a substantial disruption at school or interference with the rights of students to be secure (Layshock v. Hermitage Sch. Dist., No. 06-116 (July 10, 2007)). But school officials may not respond based on disapproval of the content or manner of the speech, however offensive, or the perspective that the student's speech is inconsistent with educational standards. When students are off-campus, parents are responsible for imparting values.

Unfortunately, the case law in this area is still developing, but most of the parameters are clear (Id). There must be a nexus between the off-campus online speech and the school community and the impact must be at school. The impact must also be material and substantial-not merely disapproval of the expression of the actions of a student. Further, the disruption must be of the school or interference with rights of students. Cases interpreting Tinker have found a number of typical situations may meet this challenge may include a significant interference with instructional activities, school activities, or school operations (Boucher v. School Board of the School District of Greenfield, 134 F.3d 821 (7th Cir. 1998)), physical or verbal violent altercations (Mahling, 1996), or the creation of a hostile environment or substantial interference with a student's ability to participate in educational programs or school activities (Saxe v. State College Area School District, 240 F.3d 200 (3rd Cir. 2001)). Further, the speech must be the actual cause of the disruption or anticipated disruption (Layshock, supra.).

In some situations, generally where the dissemination of images could be considered bullying or harassment, school officials likely do have the authority to impose discipline for off-campus sexting acts that are directed at harming a student's reputation or causing a hostile environment at school for that student. This could include situations where the act of sending the image to a recipient who does not want to 
receive it constitutes harassment, distributing an image to others, or maliciously soliciting the image.

In a situation where a student created an image and sent it privately to someone and that person has disseminated the image is highly likely not to meet these standards with respect to the student depicted. The fact that a student may have engaged in an action that is now causing him or her to be ridiculed does not mean that this student has caused the substantial disruption. It is the students who are distributing the image who are causing the disruption.

Liability for hostile environment: School officials have the responsibility to respond if a hostile environment has been created for a student on-campus if they know of the concern and have the ability to respond (Davis v. Monroe Bd. of Educ., 526 US 629 (1999)). This includes hostile environments grounded in sexual harassment. School officials may have the responsibility to respond to off-campus online speech that has created a hostile environment at school, if they know of the concern. The standards in this area are unclear.

The fact that a student has done something "stupid"-like provide a nude or semi-nude image that has now "gone viral" and has led to sexual harassmentdoes not absolve school officials of their responsibility to prevent a hostile environment and stop the sexual harassment.

Search and seizure: In 1985, the US Supreme Court, in New Jersey v. T.L.O., held that the Fourth Amendment prohibition on unreasonable search and seizures applies to searches by public school officials of students and their possessions (469 US 325 (1985)). The Court held that student searches must be reasonable-a balance between students privacy rights and the school's need to maintain order. To determine the reasonableness, two questions must be asked: (1) whether the action was justified at its beginning and (2) whether the extent of the search as conducted was reasonably related to the circumstances which justified the search in the first place. To justify a student search, reasonable grounds must exist for suspecting that the search will turn up evidence that the student has violated or is violating either the law or school policy. The TLO standard will apply to school official searches of a student's electronic device.

In 2006, a federal court in Pennsylvania applied the T.L.O. reasonableness standard in the case of Klump v. Nazareth Area School District (425 F. Supp. 2d. 622 (E.D. Pa. 2006)). In Klump, a teacher had confiscated a student's cell phone because it was visible in class, violation of a school policy that prohibited the display or use of cell phones during instructional time. An administrator then searched through the student's stored text messages, voicemail and phone number directory to determine if other students were also violating the school's cell phone policy. The student filed suit, asserting that these actions constituted an unreasonable search.

The Court determined that the district had reasonable suspicion that the display/use policy was violated, but did not have reasonable suspicion that any other law or policy had been violated. Thus, the confiscation of the cell phone was justified, but the search of the phone records violated the student's Fourth Amendment rights. In addition the Court found that the district violated the Pennsylvania Wiretap Act by accessing stored voicemail and text messages.

The issue of school official review of cell phone records when the cell phone was merely visible or used at school is also under litigation in Mississippi in the case of J.W. v. Desoto County School District (http://www.aclu.org/racial-justice/jw-v-desoto-countyschool-district).

It is also necessary to consider the implications of the recent US Supreme Court decision in Safford Unified School District v. Redding (557 US-(2009)). The Supreme Court referred to a strip search of a student as "categorically extreme intrusiveness" and indicated that the barrier for justification for such a search was extremely high. See also Beard v. Whitmore Lake School District: "Students have a significant privacy interest in their unclothed bodies" (402 F.3d 598, 604 (6th Cir. 2005)).

School officials in the Tunkhannock Area School District in Pennsylvania are currently facing litigation for violating a student's privacy by viewing nude images (School turned over girl's private nude photos to law enforcement. http://www.aclupa.org/pressroom/acluofpasuesschooldi strict.htm). A commentary that appeared in the Times Tribune entitled Electronic Peeping Toms, stated (http://thetimes-tribune.com/opinion/electronicpeeping-toms-1.807464):

It's one thing for school officials to confiscate a phone in order to enforce policy. It's quite another to search its memory as part of a fishing expedition. ... As lawmakers, the courts and schools figure out how to deal with sexting, they should pay equal attention to protecting the privacy rights of students

To search the records held on a student's digital device, a school official must have a reasonable 
suspicion that the records would reveal that a law or school policy has been violated and that search is likely to turn up evidence of that violation. The simple fact that a device is visible in school when it is not supposed to be does not justify searching the records on that device. School districts should consult with their legal counsel for guidance on the application of their state's wiretap law.

Criminal risks faced by school officials: The other issue that school officials must pay scrupulous attention to is that these are nude images of minors. Possession or distribution by an adult constitutes a federal and state felony. There are currently no statutory "exceptions" for school officials to possess or distribute these images.

Both through news reports and privately reported situations, it is clear that some administrators are not handling these images properly. The author heard of one incident where an overreacting principal sent the nude image to a dozen others asking for guidance on what to do. School administrators in Pennsylvania are currently under criminal investigation for how they handled student images (Elias and Victor, 2010):

The youths involved in $\mathrm{s}$ sexting case at Susquentia HIgh School last year are facing felony charges

Now, based on parents' complaints, the administrators who caught them might face their own consequences, creating another murky legal issue in the largely untested intersection of children, technology and pornography

Susquenita High School officials are being investigated after parents claimed pornographic images and videos from cell phones confiscated from students were "passed around" and viewed by more than just those administrators who investigated the incident

"Of course, one or two people had to see the images to determine what they were", Perry County District Attorney Charles Chenot said. "But if more than one or two top administrators saw them, there better be a good reason why"

School employees could be charged with displaying child pornography-the same charges the students involved face-if they showed the images to people not involved in the investigation, Chenot said

One assistant principal was prosecuted, although ultimately the charges were dismissed because the image itself was not deemed to be pornographic (Zetter, 2009).

Reporting and investigation protocol essential: It is imperative that school districts have a clear protocol for reporting and investigating these incidents that has been approved by their local district attorney and school district counsel. This protocol must address the standards for search and seizure, actions are necessary if students are suspected of a criminal offense including the need to contact parents before allowing a police officer to conduct an investigation unless there are indications of family-based sexual abuse and how school officials should handle nude images. It may be safest for school officials if the only actions they take with respect to the cell phones that might contain such images are to confiscate the cell phones and provide them to the police.

Multidisciplinary teams: Multidisciplinary Teams (MDTs) were described in a document from the US Department of Justice Office of Juvenile Justice and Delinquency Prevention (OJJDPP, 1998):

An MDT is a group of professionals who work together in a coordinated and collaborative manner to ensure an effective response to reports of child abuse and neglect. Members of the team represent the government agencies and private practitioners responsible for investigating crimes against children and protecting and treating children in a particular community. An MDT may focus on investigations; policy issues; treatment of victims, their families and perpetrators; o ra combination of these functions. ...

The MDT approach promotes wellcoordinated child abuse investigations that benefit from the input and attention of many different parties-especially law enforcement, prosecution and child protective services-to ensure a successful conclusion to the investigation and to minimize additional trauma to the child victim

A recent study MDTs noted that a growing body of literature has determined MDTs are an effective way to 
deliver services. Among the advantages: More accurate assessment and prediction of risk. Improved intervention. Decreased fragmentation in delivery of services. Enhanced quality of evidence. Improved quality of services. Reduction in the trauma of children. Positive influence the development and use of additional services and resources.

Given that MDTs are already present in many communities and that their membership includes the same kinds of professionals whose involvement is necessary to investigate the determine an appropriate response to sexting incidents, it makes logical sense to place the authority for oversight of sexting incidents within the MDTs. Unfortunately, not all MDTs specifically include the involvement of schools districts-an inclusion that will be necessary.

\section{Recommended legislation (Geyer, 2009):}

- Amend the laws against child pornography to allow for lesser included offenses that will ensure that if teens are involved in activity that actually meets the standards of child pornography they can be rehabilitated as juveniles

- $\quad$ Child pornography laws should only apply to situations involving sexually explicit images taken or provided under situations of sexual abuse or coercion that are distributed or possessed with intent to distribute. The person who commits the crime is the person who has engaged in abuse, coercion, or distribution of images obtained through abuse or coercion

- Amend the laws against sending inappropriate material to a minor, endangering the welfare of a minor and other relevant sex crimes laws to create a safe-harbor exception, allowing minors and young adults who are roughly the same age to legally sext, as long as the images are retained privately and to include lesser included offenses

- This would give prosecutors the ability to charge individuals in situations where a large age gap between the participants raises concerns about consent, but recognize sexting may be performed without concerns of coercion and undue pressure between teens and young adults. The lesser included offenses would allowed a tiered approach

- Amend the state law that addresses invasions of personal privacy or create a new statute that addresses three provisions that make it illegal to:

- Distribute a nude or semi-nude image of a minor
- Distribute a nude or semi-nude image without the permission of the person depicted (this will address distribution of adult images)

- Engage in malicious actions to procure or disseminate a nude or semi-nude image (a more significant criminal offense than simple distribution)

- Create and distribute an image that shows person depicted in false light as appearing nude or semi-nude (for example, merging the face shot of one person onto a nude image of another)

- Designate the Multidisciplinary Teams as being responsible for overseeing local responses to sexting situations

- Given that the MDTs already include the appropriate professionals, it makes logical sense that the MDTs should be responsible for developing/approving an investigation "protocol" for their respective regions and providing oversight for the investigation and intervention of all reports

- Consider whether or when to make this mandatory reporting. For example, situations involving more normative behavior, between like age peers, where the images have not spread may not need to be reported. Perhaps also not everyone should be a mandatory reporter. Given the incident rates, this could overwhelm the reporting system

Recommended district policies: Sexting incidents are impacting schools. It is important for districts to determine how existing policies can be applied to these situations or whether new policies are necessary. The underlying question that must be asked is when these situations meet the standards necessary to support a school disciplinary response.

Anti-bullying and harassment policies are generally grounded in the standards enunciated in the case of Tinker v. Des Moines (393 US 503 (1969)). School officials have the authority to respond to student speech if that speech has, or there are particularized reasons to believe it could cause a substantial disruption at school or interference with the rights of students to be secure. Numerous courts have applied this same standard to off-campus speech that impacts school (478 US 675 (1986)).

Districts might argue that the controlling case is Bethel School District v. Fraser, where the Court upheld the school's suspension of a high school student who, at a school assembly, nominated a peer for class 
office an explicit sexual metaphor. The Court reasoned that:

[T] he schools, as instruments of the state, may determine that the essential lessons of civil, mature conduct cannot be conveyed in a school that tolerate lewd, indecent, or offensive speech and conduct such as that indulged in by this confused boy

Fraser may provide guidance in those situations where images are being "conveyed in a school". But Fraser likely does not provide justification for school authority to impose discipline in cases where images are merely possessed or conveyed in a mutually consenting exchange.

In a leading case evaluating the constitutionality of a district bullying prevention policy, axe v. State College Area Sch. Dist then Judge Samuel Alito outlined the constitutional issues involved (240 F.3d 200, 213 (3d. Cir. 2001)). In part, Aliito indicated approval for policy language that prohibited "speech that substantially interferes with a student's educational performance":

The primary function of a public school is to educate its students; conduct that substantially interferes with the mission is, almost by definition, disruptive to the school environment

The Court, however, found there were significant concerns about a provision of the policy that allows school officials to respond to student speech that another student might find "offensive" as being overbroad and encompassing constitutionally protected expression.

Based on this background, the key question for school officials is at what point incidents involving "sexting" meet the legal standards that justify a school disciplinary response. There are situations that appear to meet constitutional standards. These would include when images are sent in a harassing manner, that is the recipient of the image did not consent to receive or welcome the image. Situations that would also presumably meet constitutional standards are where the image is being forwarded to others without the permission of the student depicted and when a student has either maliciously obtained or is maliciously using an image, such as using the possession of an image as blackmail.

Situations where discipline are likely not justified are where a student is privately possessing an image and where images have been shared consensually with no further sharing beyond the consensual parties. School officials may argue that they have a responsibility to inculcate values or the possession of these images are a violation of the law. But if the images are not significantly impacting the school or other students, school officials have no responsibility to seek to usurp the role of parents in inculcating values. The fact that a student might have committed a criminal offense, if not committed at school, does not provide the justification for a school disciplinary response.

It is also exceptionally important that the responses to these situations be based on who actually has caused the harm and that the disciplinary responses are applied in a manner that is gender neutral. A district in Washington is being sued because it allegedly banned a cheerleader from the squad for sending an image, but did not ban the football players who were distributing her image without her consent (Soronen, 2010).

A situation that must be handled very delicately is when a student has been pressured to provide an image or has sent an image with the expectation that it would remain private and that image has been disseminated. The student or students who are at fault in this situation and should receive discipline are the one(s) who provided the coercion to produce the image or are distributing the image. Imposing a disciplinary consequence on the student who is depicted can contribute to profound harm.

The situation of Hope Witsell provides vitally important guidance in this matter (Inbar, 2009). On one occasion she sent a nude image to a boy she liked. Another girl found the image on the boy's phone and sent it throughout the school. Later, on a school field trip, she was coerced by a group of boys to provide an image. The result of these actions was intense bullying at school. When the school officials found out they suspended Hope for a week and refused to allow her to be a leader in the extracurricular organization that she was very active in. Shortly after the school-imposed discipline, Hope committed suicide.

School officials MUST understand the significant damaging effect of imposing discipline on a student in this kind of a situation. This student is likely already facing excessive peer harassment. The expression of adult disapproval through the imposition of discipline can act to justify the peer harassment in the minds of the other students. This can result in placing this student in a position of extreme emotional distress, with the significant likelihood of leading to school avoidance and failure and, in some cases, of self-injury.

The other key issue from a policy perspective is the need to encourage students to report when an image 
starts to be distributed, so that the distribution can be more limited. There are several issues that can act as a disincentive to such reporting: (1) The prospect that the student who reports will be hauled out of school in handcuffs under arrest for possession of a nude image. This would be a fear based on some of the current messaging law enforcement has been providing. (2) The student will be disciplined for violating a rule against using a cell phone during school hours. (3) The cell phone will be confiscated for evidence, thus making it impossible for the student to remain in contact with peers. It is necessary to find a way to ensure reporting, but also not allow reporting to be used in a malicious manner, that is, pressuring a student to provide an image and then reporting that student.

Addressing the first concern will require discussions with law enforcement about their messaging and what assurances they can provide related to the potential of prosecution of a student who reports who is otherwise not blameless. The second issue may be addressed with a policy provision that provides immunity from discipline for inappropriate use of the cell phone during the school day or possession of an image if a student makes a report and is also found not to have engaged in any contributing harmful acts. Addressing the last concern will also require discussions with law enforcement. Possibly an arrangement could be made that pictures are taken of the evidence on the phone, which is then inappropriate images are then deleted and the cell phone returned. Possibly each school could maintain a collection of used cell phones that could be provided as loaners if it is necessary to retain a student's personal phone. Possibly some form of financial reward for students who report may provide encouragement, especially if that student will be inconvenienced by the loss of a cell phone. All of these issues should be discussed with local law enforcement.

Multidisciplinary investigation and intervention protocol: Given the potential criminal issues involved, it is imperative that a protocol be developed that will provide guidance to school officials in responding to sexting incidents that they become aware of or are impacting schools. This protocol must be developed in cooperation with and the approval of the local district attorney. The protocol also should be approved by the district's legal counsel. In the context of the development of this protocol, school officials should encourage a tiered approach to responding to these situations that focuses on education and rehabilitation.

In some reported incidents, students have been hauled away from school in handcuffs, sometimes without parents being notified (WDBJ7, 2010). This approach can have a profoundly disturbing impact on the entire school community and can cause significant emotional harm to the students who are arrested. School officials must seek to avoid having this kind of an incident occur.

Even absent a specific state law specifically directing that MDTs take responsibility for oversight of the sexting concern, it makes logical sense for the MDTs to develop a local protocol for how to investigate and respond to these cases. Further, these situations may well fall under a reading of the existing language.

Special consideration will need to made about who should interview the students, especially the student who is depicted. This student can be anticipated to be in a situation of extreme emotional distress due to the fact that the image they created, likely believing it would remain public, has now been discovered. The investigation of this student should likely be accomplished a school professional who has an excellent rapport with the student, such as a counselor, by a law enforcement official with specific training in working with sexual abuse victims, or a child protection worker. Every effort must be made to ensure that news of the incident is not spread.

\section{CONCLUSION}

Recommendations for a reporting, investigation and intervention protocol:

- It is imperative that schools districts have a protocol to guide reporting and investigation that has been developed in collaboration with and approved by the local district attorney and has been approved by district counsel

- An important role of school officials in developing such a protocol is to address the concerns of law enforcement that wants to take a "tough on crime" approach to trying to prevent sexting:

- Ensure the involvement of mental health professionals $\sim$ hopefully through the MDT

- Encourage prevention and a balanced, tiered approach to intervention

- Reduce the emotional trauma to the involved students. There is NO need to haul students out of school in hand-cuffs

- The following protocol can serve as a model, but obviously must be approved locally

- Establish a multidisciplinary investigation team within the school includes the principal, 
counselor/psychologist and school resource officerwith back-up from district legal and risk prevention services:

- Make sure all district personnel know who they should report situations to and how images and cell phones should be handled

- Make sure all principals have a clear understanding of the search and seizure standards that have been approved by the local district attorney and school district legal counsel

- My personal recommendation is that principals should avoid ever looking for or at any nude image of a minor unless under specific direction from a law officer

- Once reported, strive to stop further dissemination of the images:

- Make sure students know that cell phone distribution paths can be traced and if they are found to have distributed an image, this will result in suspension

- Promise confidentiality for student reports about such distribution

- Confiscate the cell phones of the students who are suspected to be involved. But do not search without first contacting law enforcement

- Make sure parents are contacted as early as possible

- $\quad$ Strive to keep these incidents out of the news, if possible. If news coverage does occur, ensure statements made will minimize the emotional harm to the teens depicted. Talk with media about concerns related to such harm:

- News of these situations will expand news of the incident and could lead to further dissemination of the images. This will likely increase the emotional harm to the students depicted and the sexual harassment they will receive on campus $\sim$ making it impossible to safely come to school. School officials must seek to prevent a hostile environment

- Establish parameters for how and when incidents should be reported to the MDT and investigated. Recommendations are as follows:

- Immediately report situation to MDT and based on what is known at the time, make a decision about who will take the initial lead in conducting an investigation

- Recognize that the student (s) depicted could potentially be in a situation of severe emotional distress. Insist that whoever interviews a depicted student has professional training in working with sex abuse victims
- In consultation with the MDT, determine how and when to contact parents. Most district policies require contacting a parent prior to any investigation, unless there are familyrelated sexual abuse concerns

- As names of participants are identified, immediately transmit these to the MDT to determine whether there are any prior records.

- Discuss findings and propose plan for further investigation or intervention

- Routinely evaluate the report, investigate and intervene protocol as applied to situations to determine effectiveness of the protocol and develop better prevention

\section{Investigation questions:}

Initial questions: Who are participants? What is the difference in ages? Who is depicted? Who created or facilitated the creation of the image and how? Did person depicted know the image was created and approve? Who sent image? Where and how was it sent, to whom, to how many people? How did it spread after initial distribution? Was the image distributed at school? Is there evidence of a faked image or of abuse of teen?

Self-initiation or pressure: Creation Initiated by Person Depicted. (May have been facilitated by someone else):

- Was the image also disseminated by the person depicted? If so, who was the image initially sent to and for what apparent purpose?

- Romantic partner? Desired romantic partner? What are the actual circumstances?

- For attention-getting? Peer group "game"?

- As a form of harassment? The equivalent of "up yours" or "mooning/" To shock or "gross people out"?

- Solicitation? Sexual hook-up interest? Equivalent age peers? Solicitation of younger teens? Prostitution? Was recipient known in person or only online?

\section{Creation initiated in response to "pressure":}

- What kind and degree of "pressure?" Was this a request, sweet-talking, manipulation, false promise, coercion, threat, invasion of privacy? By someone known or known only online?

- Non-malicious pressure from a romantic partner, with no intent to share? Nonmalicious pressure in a group "game" that got out of control? 
- Malicious pressure in a group with a malicious leader, "in-crowd" students seeking images of "wannabes", or an individual bully all with plans to disseminate?

- Person used coercion, threats, false promises to trick or convince person into creating or allowing creation of image? Was this an abusive partner?

- Invasion of privacy (locker room) to create image?

\section{Dissemination:}

- If image has been disseminated, how widely has it been distributed, who was most actively distributing and what was the apparent intent of all participants in the dissemination?

- Self-sharing or non-malicious sharing with small number of friends, not thinking that anyone would further disseminate?

- Maliciously shared after a break-up of a relationship?

- Image was not disseminated by person depicted or his/her friend who possessed the image, but was found by someone who gained access to the digital device and disseminated maliciously. Find out who had access to device?

- Intentional and malicious wide distribution by someone who obtained either from person depicted or from someone else who had obtained it?

- Disseminated by person depicted for attentiongetting or sexual solicitation purposes?

- If image has not been widely disseminated, is image being used for blackmail?

\section{Incident intervention:}

Developmentally normative:

- Impose mild level restorative justice school discipline for any students who violated trust-if there has been a substantial disruption at school or creation of a hostile environment for any student (s) depicted

- Consider juvenile court review in some situations leading to informal disposition, deferred prosecution, or diversion for anyone violated trust and distributed image outside of relationship or group

\section{Harassment:}

- Impose more significant restorative justice school discipline for any students who engaged in harassment activities
- Implement juvenile court review of circumstanceswhich could lead to informal disposition, deferred prosecution, diversion, or detention-depending on egregiousness of situation:

- Possible charges include: Harassment. Invasion of privacy. Disorderly conduct. Malicious acquisition or distribution. False light

- The reason for juvenile jurisdiction is to ensure a disciplinary consequence, as well as supervision and rehabilitation

\section{At-risk:}

- Impose school discipline only appropriate if at-risk behavior constituted sexual harassment of other students

- Implement juvenile court review of circumstanceswhich could lead to informal disposition, diversion, status offense, or detention-depending on degree/manner of risky behavior

- Possible charges include: Harassment. Indecent exposure. Solicitation. Prostitution

- The reason for juvenile jurisdiction is to ensure counseling, supervision and rehabilitation

\section{Exploitive:}

- Impose significant restorative justice school discipline for any students who engaged in harassment activities

- Implement juvenile court review of circumstanceswhich could lead to informal disposition, diversion, status offense, or detention, depending on degree/manner of harmful behavior:

- Possible charges include: Harassment. Malicious acquisition or distribution. Stalking. Blackmail. Solicitation or exploitation. Child pornography

- The reason for juvenile jurisdiction is to ensure a disciplinary consequence, as well as counseling, supervision and rehabilitation

\section{Young adult students:}

- How law enforcement will handle situations of over-18 students engaged in unlawful behavior is out of the hands of the MDT or school officials:

- The MDT should advise against an overreaction. Most often, these are teens in a peer environment who simply do not understand the implications 
- Encourage use of lowest level of criminal charges and avoidance of any charges that could result in required registration as a sex offender. Given the degree of normality of these incidents, registration as a sex offender will rarely be justified, would destroy the future of this student and provide no community protection against future sexual abuse whatsoever

\section{Prevent sexual harassment:}

- Articulate a plan to stop anticipated sexual harassment of the student (s) depicted:

- Schools have a legal obligation to prevent sexual harassment of students-regardless of whether the student has engaged in behavior that contributed to this

- Implement a plan to provide emotional support:

- The student depicted is likely at risk for severe emotional distress and may need to be on "suicide watch"

\section{AKNOWLEDGEMENT}

Author notes the incredibly helpful insight that has been provided in the creation of this report by Anne Collier, of Connect Safely and NetFamilyNews, Elizabeth Englander of the Massachusetts Aggression Reduction Ceneter, Patti Agatston, Prevention Specialist with Cobb County Schools, Georgia, Mike Donlin, Program Manager Prevention/Intervention for Seattle Public Schools, Sameer Hinduja, Associate Professor in the Department of Criminology and Criminal Justice at Florida Atlantic University, Justin Patchin, Associate Professor of Criminal Justice in the Department of Political Science at the University of Wisconsin-Eau Claire.and Jim Hargreaves, Retired Lane county Circuit Judge. However, the author bears responsibility for the opinions expressed in this report.

\section{REFERENCES}

Alspach, K., 2010. Accused brockton high sexting student: "I did not take this video". Patriot Ledger. http://www.patriotledger.com/news/cops_and_cour ts/x1672009517/Accused-Brockton-High-sextingstudent-I-did-not-take-this-video

Chaffin, M., 2008. Our minds are made up-don't confuse us with the facts: Commentary on policies concerning children with sexual behavior problems and juvenile sex offenders. Child Maltreat., 13: $110-121$. DOI: $10.1177 / 1077559508314510$
Cohen, S., 1972. Folk devils and moral panics: the creation of the mods and rockers. LibraryThing. http://www.librarything.com/work/102467

Davis, N.S. and J. Twombly, 2000. State legislators' handbook for statutory rape issues. US Department of Justice Office of Victims of Crime. http://www.ojp.usdoj.gov/ovc/publications/infores/ statutoryrape/handbook/statrape.pdf

Duffy, S.P., 2010. 3rd circuit panel mulls if teen 'sexting' is child pornography. The Legal Intelligencer. http://www.law.com/jsp/article.jsp?id=1202439023330

Elias, J. and D. Victor, 2010. Susquenita high school officials being investigated for handling of images in 'sexting' case. The Patriot News. http://www.pennlive.com/midstate/index.ssf/2010/ 04/susquenita_high_school_officia.html

Feyerick, D. and S. Steffen, 2009. 'Sexting' lands teen on sex offender list. CNN http://www.cnn.com/2009/CRIME/04/07/sexting.b usts/index.html

Finklehor, D., K. Mitchell and J. Wolak, 2001. HIghlights of youth internet safety survey. OJJDP Fact Sheet. http://www.ncjrs.gov/pdffiles1/ojjdp/fs200104.pdf

Geyer, H., 2009. Sexting-the inappropriateness of child pornography laws. Juvenile Justice E-Newsletter. http://www.abanet.org/crimjust/juvjust/newsletterj une09/june09/sexting.htm

Keelty, C., 2010. Sexting and what it means to be a girl. ACLU Blog of Rights. http://www.aclu.org/blog/free-speech/sexting-andwhat-it-means-be-girl

Knutson, R. and J. Scheck, 2009. Sex-registry flaws stand out. Wall Street J. http://online.wsj.com/article/SB125194251857582 015.html

Leshnoff, J., 2009. Sexting not just for kids. AARP. http://www.aarp.org/family/love/articles/sexting_n ot_just_for_kids.html

Mahling, W., 1996. Secondhand codes: An analysis of the constitutionality of dress codes in the public schools. Heinonline. http://heinonline.org/HOL/LandingPage?collection $=$ journals $\&$ handle $=$ hein.journals $/ \mathrm{mnlr} 80 \& \operatorname{div}=27 \&$ $\mathrm{id}=\&$ page $=$

McElroy, W., 2010. News item: Sexting leads to felony charges for children. Ifeminists.com. http://www.ifeminists.com/print.php?news.15346

Mordan, R., 2008. Revenge porn: Jilted lovers are posting sex tapes on the Web-and their exes want justice. Details.com. http://www.details.com/sexrelationships/porn-andperversions/200809/revenge-porn 
Inbar, M., 2009. 'Sexting' bullying cited in teen's suicide. TODAY show.

http://today.msnbc.msn.com/id/34236377/ns/todaytoday_people/

OJJDPP., 1998. Forming a multidisciplinary team to investigate child abuse. US Department of Justice. http://www.ncjrs.gov/pdffiles1/ojjdp/170020.pdf

Pawloski, J., 2010. Three Lacey teens face felony 'sexting' charges. The News Tribune. http://www.thenewstribune.com/news/local/story/1 049981.html

Pfeifer, W., 2009. Too many registered sex offenders make dangerous sex offenders difficult to track. The Examiner. http://www.examiner.com/x-16813Legal-News-Examiner y2009m9d4-Too-manyregistered-sex-offenders-makes-dangerous-sexoffenders-difficult-to-track

Rau, A.B., 2010. Arizona senate panel endorses 'sexting' bill. The Arizona Republic. http://www.azcentral.com/news/articles/2010/02/0 3/20100203sexting-bill-arizona.html

Roush, W., 2006. The moral panic over social networking sites. Technology Review. http://www.technologyreview.com/communication s/17266/
Seidel, J., 2010. Legislative shuffle enters final stages. Post Tribune.

Soronen, L.E., 2010. Sexting at school: Lessons learned the hard way. National School Boards Association. http://www.nsba.org/MainMenu/SchoolLaw/Issues /Technology/Resources/IA-Feb-10.aspx

Swift, R., 2010. House panel looks for lesser sexting penalty. Republican Herald. http://republicanherald.com/news/house-panellooks-for-lesser-sexting-penalty-1.574980

WDBJ7, 2010. Franklin county students arrested for sexting. WDBJ7.

Wolak, J., D. Finklehor and K. Mitchel, 2009. Crimes against trends in arrests of "online predators". Children Research Center. http://www.unh.edu/ccrc/pdf/CV194.pdf

Zetter, K., 2009. 'Sexting' hysteria falsely brands educator as child pornographer. Wired Magazine. http://www.wired.com/threatlevel/2009/04/sextinghysteri/ 